\title{
Influence of physical forcing on the spatial distribution of marine fauna near Resolution Island (eastern Hudson Strait)
}

\author{
C. Hudon ${ }^{1, *}$, R. E. Crawford ${ }^{2, * *}$, R. G. Ingram ${ }^{3}$ \\ ${ }^{1}$ Department of Fisheries and Oceans, Arctic Biological Station, 555 Boul. Saint-Pierre, Sainte-Anne de Bellevue, Quebec, \\ Canada H9X 3R4 \\ ${ }^{2}$ Department of Fisheries and Oceans, Freshwater Institute, 501 University Crescent, Winnipeg, Manitoba, Canada R3T 2N6 \\ ${ }^{3}$ Department of Atmospheric and Oceanic Sciences, McGill University, 805 Sherbrooke St. West, Montreal, Quebec, \\ Canada H3A 2K6
}

\begin{abstract}
The vertical and horizontal distribution of zooplankton, pandalid shrimp and fish were studied off Resolution Island (eastern Hudson Strait) using a multistage plankton sampler (BIONESS), acoustic echo integration and bottom trawling. Zooplankton concentration was highest above a submarine trench extending into the study area. The depth of the center of mass of the vertical distribution of most zooplankters was related to total depth. In addition, the diel vertical distribution of shrimps and mysids was correlated with light levels, suggesting active movements. Diel vertical movements of chaetognaths and copepods were correlated with tidal amplitude and isopycnal depth, suggesting passive displacement. Horizontally, shrimp and fish biomass was concentrated in and above the trench, indicating retention within the benthic boundary layer. It is postulated that the combination of bathymetric features and current conditions of Resolution Island generates a persistent eddy-like structure leading to the passive accumulation of the zooplanktonic prey of shrimp. Local retention of pandalid shrimp is attained by their daytime concentration in the deeper waters of the trench within the benthic boundary layer and their retention within the gyre during their nighttime planktonic feeding forays.
\end{abstract}

\section{INTRODUCTION}

Technological improvements in biological sampling gear have allowed more detailed study of oceanic phenomena occurring at smaller spatial and temporal scales, bringing a new awareness of the inherent variability in marine systems. In this respect, acoustic sampling was shown to be a powerful tool (Sprong et al. 1990, Crawford et al. 1992) for high-resolution studies of small-scale processes (Denman \& Powell 1984, Legendre \& Demers 1984). This approach focusses on how and why the biological patterns develop and what maintains them (see the review of Haury \& Pieper

\footnotetext{
Present addresses:

- Environnement Canada, Centre Saint-Laurent, 105 ave. McGill, $4^{\circ}$ ét., Montréal, Québec, Canada H2Y 2E7

- Waquoit Bay National Estuarine Research Reserve, PO Box 3092, Waquoit, Massachussetts 02536, USA
}

1987). Ultimately, the distribution of organisms is the end-product of the interactions among animal morphology, behaviour and physical forces, all operating at different scales.

There is growing evidence for increased residence time in eddies generated by bathymetric and coastline features (e.g. Boucher et al. 1987). In addition, shelf break and areas of bathymetric irregularities are increasingly reported as sites of high zooplankton concentrations (Herman et al. 1981, Le Fèvre \& Frontier 1988). Turbulence, tidal currents, internal waves, fronts and upwelling can also alter the vertical distribution of zooplankters (see Mann \& Lazier 1991). The phenomena generating variability in the horizontal distribution at a 1 to $100 \mathrm{~km}$ scale can be used to determine retention mechanisms in distinct areas, which is of crucial importance for fisheries stock definition (Sinclair \& Iles 1989).

This study examines the horizontal and vertical distribution of organisms in the highly energetic area of 
eastern Hudson Strait and the physical processes that may be responsible for the local retention of microand macrozooplankters. Data were originally gathered to study the distribution and feeding of shrimp Pandalus montagui during their movements off the bottom (Crawford et al. 1992, Hudon et al. 1992). An a posteriori examination of data suggested the influence of bathymetry on the meso-scale (km) distribution of pelagic and migratory zooplankters over a wide range of sizes, which prompted the present analysis

\section{STUDY AREA}

Hudson Strait extends over $750 \mathrm{~km}$ in length from its eastern boundary with the Labrador Sea to its western connection with Foxe Channel (Fig. 1). It acts as a transition zone between the less saline waters of Hudson Bay and the more oceanic Labrador Sea (Drinkwater 1986). The average width of the strait is $150 \mathrm{~km}$, with a minimum of $70 \mathrm{~km}$ near Resolution Island. Midchannel depths range from 300 to $400 \mathrm{~m}$, with a deep basin $(1000 \mathrm{~m})$ just west of its eastern boundary. A sill $(<400 \mathrm{~m})$ marks the eastern end of the basin. Off Resolution Island, tidal amplitudes are in the order of 6 to 9.5 m (Canadian Hydrographic Service 1988) and residual surface currents are about 15 to $20 \mathrm{~cm} \mathrm{~s}^{-1}$ (Drinkwater 1986). Sea ice usually covers much of the strait from mid-December to July.

Over the last 20 yr, data from hydrographic observations, current meter moorings, drogues and satellite imagery have been used to characterize the circulation and water mass properties in Hudson Strait (LeBlond et al. 1981, Drinkwater 1983, 1986, 1988, 1990, Cherniawsky \& LeBlond 1987). Waters near the northwest part of Resolution Island are under the influence of the Baffin Island current, which enters Hudson Strait from the north via Gabriel Strait (Fig. 1). Density stratification parameters calculated for this area identify it as a transition zone (Drinkwater \& Jones 1987) with a frontal area in Gabriel Strait, where swift tidal currents are observed (Canadian Hydrographic Service 1983). Near the southwest edge of the island, a bank $(<300 \mathrm{~m})$ is contiguous with the deepening waters at the entrance to Hudson Strait, where intense mixing also takes place (Drinkwater \& Jones 1987).

Water temperature increases with depth below $200 \mathrm{~m}$ to reach a maximum of nearly $2^{\circ} \mathrm{C}$ around $400 \mathrm{~m}$, reflecting the influence of the deeper Labrador Sea water. This water mass is transported into the Strait through the deep central trench extending along the axis of eastern Hudson Strait (Drinkwater 1986). Spatial differences in the rates of vertical mixing by the tides led Griffiths et al. (1981) to predict the presence of fronts southeast of Resolution Island. Drinkwater \&
Jones (1987) found evidence for these tidal fronts and documented their influence on nutrients and chlorophyll. The mixing of Arctic and Labrador Sea waters occurs off the southwest edge of the island across the mouth of Hudson Strait, and is characterized by a frontal region of highly mixed waters and high nearsurface nitrate and chlorophyll concentrations (Drinkwater \& Jones 1987). This area coincides with the location of commercially exploited shrimp concentrations in eastern Hudson Strait (Hudon 1990), suggesting that the distribution of the living resources may be physically controlled.

\section{MATERIAL AND METHODS}

Sampling. Sampling took place from August 22 to September 2, 1988, in an $800 \mathrm{~km}^{2}$ study area west of Resolution Island (Fig. 1), where high shrimp catches by the commercial fishery had been made in previous years (Hudon 1990). An acoustic survey of the study area was made using a $120 \mathrm{kHz}$ single-beam transducer towed 60 to $100 \mathrm{~m}$ below the surface. The survey was designed to study the distribution of shrimp in the study area, while accounting for their diel vertical migration off the bottom. Two target strengths derived from an examination of the literature were used in estimating shrimp biomass. Specific details are provided in Crawford et al. (1992). Acoustic observations were also conducted simultaneously during the BIONESS sampling (see below).

The abundance and distribution of demersal fish and shrimp in the study area derived from the acoustic survey were supplemented by trawling as a means to groundtruth the data. Twenty-four bottom traw] tows were made using a Sputnik 1600 shrimp trawl with a $13 \mathrm{~mm}$ mesh lining in the codend (Parsons et al. 1990). Tow data included the date, time, position (lat., long.), depth, and light intensity. Predominant species were identified, weighed, measured, and their abundance was standardized to a $0.5 \mathrm{~h}$ tow duration. The horizontal distribution of shrimp and fish captures $(\mathrm{kg}$ per standard 0.5 h tow) over the study area was mapped (Crawford \& Fox 1992).

The small-scale vertical distribution of zooplankton at 3 locations in the study area was studied with a Bedford Institute of Oceanography Net and Environmental Sensing System (BIONESS; Sameoto et al. 1980). The sampler was fitted with an Applied Microsystems salinity-temperature-depth (STD) recorder BIONESS sampling was conducted every $2 \mathrm{~h}$, for 3 series of 13,27 and 27 h respectively $(8,13$, and 13 sets respectively). Each BIONESS set was made at about $3 \mathrm{~m} \mathrm{~s}^{-1}$, using nine $1-\mathrm{m}^{2}$-aperture nets (five of 500 and four of $333 \mu \mathrm{m}$ mesh). The descending part of each set was made with 
all nets closed and was used to obtain an STD profile. The first net was opened at a mean height of $12.5 \mathrm{~m}$ above the bottom, and sampled upwards over a 25 m layer. The next 6 nets were opened sequentially at each $25 \mathrm{~m}$ interval, and the final 2 nets sampled a $50 \mathrm{~m}$ stratum, the last obliquely to the surface. Each net was open for about 3 min, filtering approximately $450 \mathrm{~m}^{3}$ of water. Filtering efficiency, calculated as the ratio of internal to external flowmeter values, always exceeded $65 \%$. A total of 34 sets (306 samples) were made. Tide elevation $(\mathrm{m})$ at the beginning of each set was derived from tide tables (Canadian Hydrographic Service 1988). Surface light intensity was measured at the beginning of each set with a photometer (Gossen Luna 6).

The first BIONESS series of sets were made with $500 \mu \mathrm{m}$ mesh nets sampling the deep layer (nets 1 to 5 , bottom to $250 \mathrm{~m}$ ), and $333 \mu \mathrm{m}$ mesh nets sampling the surface layer (nets 6 to 9, $200 \mathrm{~m}$ to surface). The order of the nets was inverted for the third series, to account for potential bias in the vertical distribution of smallest zooplankton. Zooplankton samples were preserved in $10 \%$ formalin, sorted into major taxonomical groups (or by species where possible), counted and weighed (wet weight; to nearest $0.01 \mathrm{~g}$ ) after removing excess water by holding on a $333 \mu \mathrm{m}$ nitex sieve. For each sample (i.e. the contents of one net), the numerically dominant species in each major group was recorded. The abundance of individual instars of 5 abundant copepod species was evaluated in a subsample for each sample. For each commonly encountered copepodite stage ( 5 species), as well as for the 10 macrozooplankters most frequently encountered, an individual wet weight was determined by weighing several ( 2 to 829 ) animals originating from a number ( 2 to 9 ) of samples. The copepodite stages of the 5 most common species were enumerated. Densities of each group of zooplankters were calculated in $\mathrm{mg} \mathrm{m}^{-3}$ for each sample, and used for further calculations.

Data analyses. The depth of the center of mass (ZCM) of zooplankton was calculated as:

$$
\mathrm{ZCM}=\sum p_{i} z_{i}
$$

where $p_{i}=$ the proportion of the total biomass of organisms caught within the ith depth interval $\left(\sum p_{i}=1\right)$; and $z_{i}=$ the mid-depth of the ith interval.
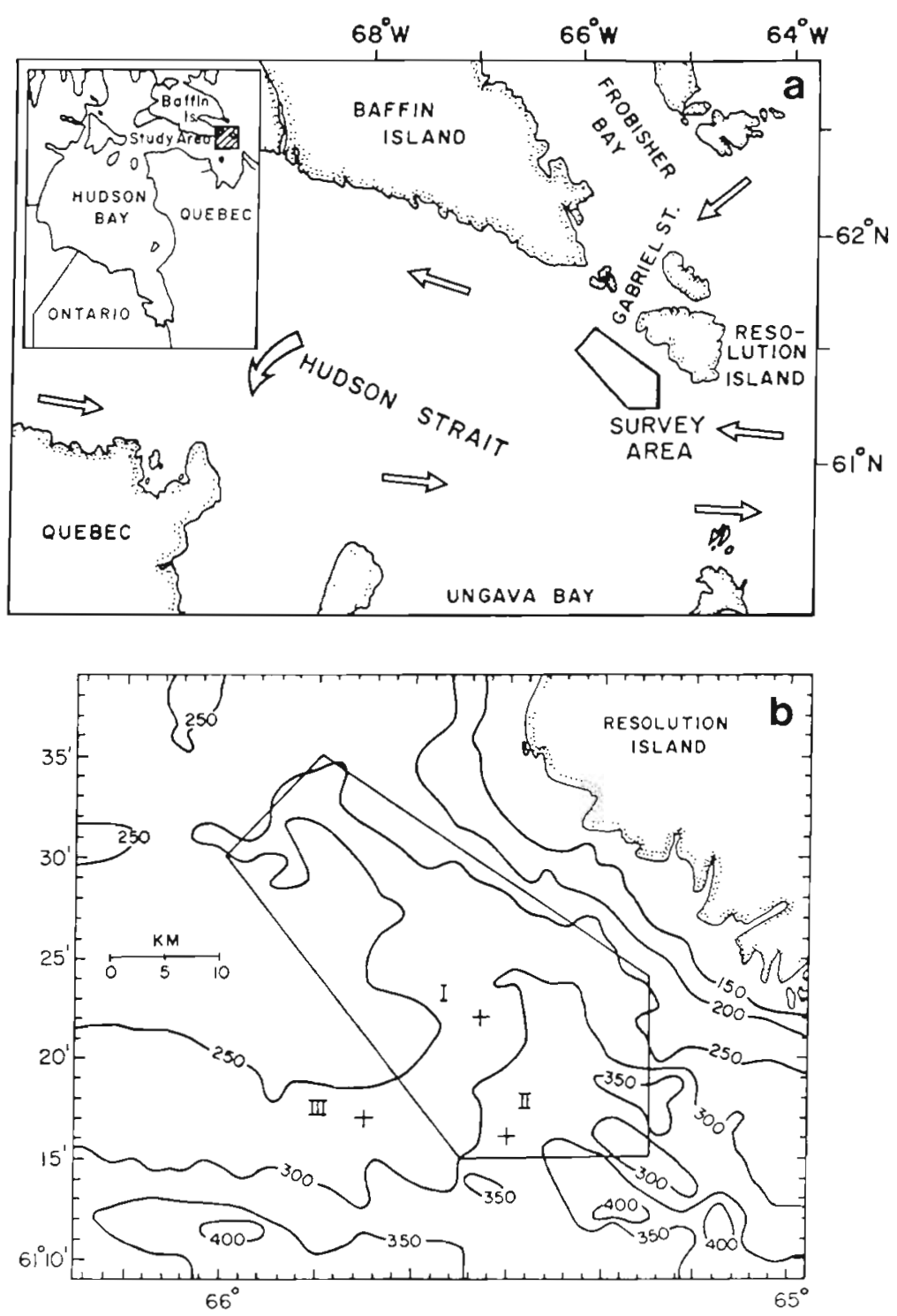

Fig. 1 (a) Location of the study area, west of Resolution Island, in eastern Hudson Strait (inset). Arrows indicate the direction of mean currents (adapted from Drinkwater 1986). The study area (pentagon) where acoustics and trawling were carried out was based on the sites of large shrimp catches in previous years. (b) Locations of BIONESS Series I, II and III with respect to the bathymetry (meters)

Pearson I correlations between the ZCMs of the different groups were calculated to determine if their center of mass oscillated synchronously in the water column. The occurrence of differences of ZCM between BIONESS series for each group of organisms, and between each group for all series, was tested with 1-way ANOVAs. ZCM values were square-root transformed to homogenize the variance between groups.

The invertebrates collected in the BIONESS belonged to 11 taxonomical groups, among which size and swimming abilities varied widely. Relations be- 
tween swimming/sinking speed and wet weight were derived from the literature. Measurements of cruising speeds of longer durations were preferred to shortterm measures. For crustaceans, the speed of swimming upwards was estimated from a linear regression between long-duration (>30 min) speed measurements $\left(\log _{10} \mathrm{~cm} \mathrm{~s} \mathrm{~s}^{-1}\right)$ reported for various species (Hardy \& Bainbridge 1954) and their estimated average wet weight $\left(\log _{10} \mathrm{mg}\right)$. Passive sinking speed was estimated from the rough value of 1 body length $\mathrm{s}^{-1}$ (Rudyakov \& Tseitlin 1980).

Non-parametric correlations (Spearman rank) were calculated between physical (total depth, light intensity, tide elevation, isopycnal depth) and biological (ZCM) variables for different groups. Horizontal differences in zooplankton concentrations were detected using 1 -way ANOVAs made on $\log _{10}(x+1)$ transformed concentrations ( $\mathrm{mg}$ wet weight $\mathrm{m}^{-3}$ ) between BIONESS series.

\section{RESULTS}

\section{Physical conditions}

Acoustic observations indicated that the 3 BIONESS series were located in areas of different bottom topography: Series I and II were done at the edge and in the deep part (respectively) of a trench cutting across the bank, whereas Series III was located on the same bank away from the trench (Figs. 1b \& 2a). All 3 series consisted in nighttime and daytime sets (Fig. 2b). Dusk started at about 18:00 h local time, and complete darkness was observed by 21:30 h. Morning intensities increased rapidly between 05:00 and 08:00 h.

The study occurred during spring tides with maximum amplitude of $8 \mathrm{~m}$ in Acadia Cove (Resolution Island) on August 30 (Canadian Hydrographic Service 1988). Tidal amplitudes were 4 to 5,6 to 8 and 5 to $7 \mathrm{~m}$ during 810 NESS Series I, II and III, respectively (Fig. 2c). STD profiles made concurrently with biological sampling indicated the predominance of well-mixed waters throughout the study area, but coverage was insufficient to determine the occurrence of any large-scale retentive structure. A positive correlation was observed between temperature and salinity at the bottom ( $\mathrm{r}=$ $0.878, \mathrm{n}=34, \mathrm{p}=0.0001)$. Isopycnal depth $\left(\sigma_{\mathrm{t}}=27.0\right)$ was negatively correlated to bottom temperature $(r=-0.649$, $\mathrm{n}=34, \mathrm{p}=0.0001)$ and salinity ( $\mathrm{r}=$ $-0.535, n=34, p=0.0001$.). Calculation of partial correlation coefficients showed that only temperature exerted a significant influence on isopycnal depth, once the effect of salinity was held constant $\left(\mathrm{r}_{\text {SI.T }}=0.1418\right.$, $\mathrm{p}=0.6237 \mathrm{r}_{\text {TI.S }}=-0.7748, \mathrm{p}=0.0109$ ) Tidal amplitude, as determined from the tables, was not correlated with any other physical variable.

In addition to the semi-diurnal periodicity of the isopycnal oscillations, there was evidence of higher frequency variations and shoaling of the $27.0 \sigma_{t}$ isopleths (Fig. 2a). Readily apparent in

Fig. 2. Physical conditions during sampling for vertical distribution of zooplankton during the 3 consecutive BIONESS time series. (a) Total depth and depth of isopycnal 27.0 at the beginning of each set. (b) Surface light intensity. (c) Tidal amplitude. The time interval between successive data points is approximately $2 \mathrm{~h}$ 
all 3 series is the weak stratification of the water column and the large amplitude of the vertical oscillations of the density field. Density differences over the entire water column were generally less than $0.8 \sigma_{\mathrm{t}}$ units.

Differences among series suggested that the shoaling of isopleths might be related to spatial rather than temporal variability. Mean $\sigma_{1}$ values for the second series were intermediate to those before and after. At mid-depth, peak to peak values of $150 \mathrm{~m}$ for the $27.0 \sigma_{1}$ isopleth were observed in the second series. In computing the mean density at 75, 150 and $200 \mathrm{~m}$ for each series, one finds a positive difference of 0.22 to $0.23 \sigma_{\text {, }}$ units between the first and third series at all 3 depths.

\section{Horizontal distribution of organisms off Resolution Island}

Trawl and acoustic data independently showed that shrimp were concentrated in 2 portions of the study area. Highest concentrations were found in the southern corner (the deepest part of the study area), whereas a lesser concentration was located about $18 \mathrm{~km}$ away, near the center of the study area (Fig. 3). Since the distributions using each gear were generated from data collected as much as 1 wk apart, their similarity suggests that the horizontal distribution was fairly stable for this period and indicates a possible link between shrimp density and bathymetric features. Several species of demersal and pelagic fishes exhibited higher densities in the areas of shrimp concentration as well (Fig. 3). The areas of shrimp and fish concentrations correspond to 2 areas of different bottom topography: a deep $(>300 \mathrm{~m}$ ) trench at the southeastern end and its shallower (250 to $300 \mathrm{~m}$ ) continuation towards a central bank (Fig. 1).

\section{Zooplankton species composition and abundance}

The distribution of zooplankters collected in the BIONESS samples (Table 1) also showed considerable horizontal patchiness. Total wet weight per unit of sea surface area was significantly higher $\left(25.12 \mathrm{~g} \mathrm{~m}^{-2}\right)$ for BIONESS Series II than for
Series I and III (14.36 and $16.29 \mathrm{~g} \mathrm{~m}^{-2}$, respectively). This difference persisted when the concentrations of organisms were compared per unit of volume (Table 2). BIONESS Series II, which was located just above the trough, exhibited the highest average concentrations of shrimp, hyperiid amphipods, euphausiids, and cope-
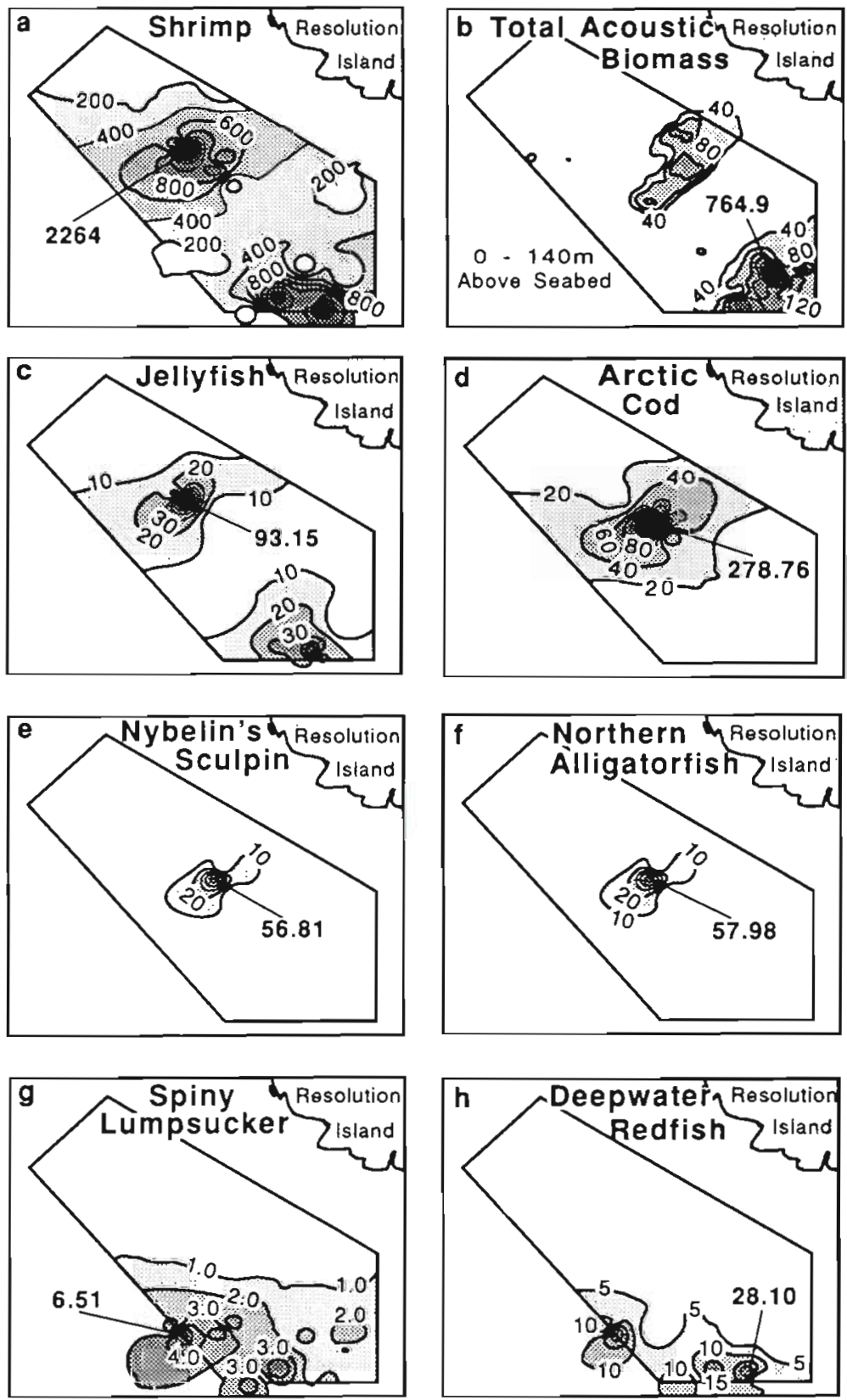

Fig. 3. Horizontal distribution (density contour isopleths and data points are in $\mathrm{kg}$ wet weight per $0.5 \mathrm{~h}$ tow) of invertebrates and fish in the study area interpolated from Sputnik trawl catches (except for b). (a) Pandalus montagui, (b) total biomass from acoustic data, (c) jellyfish, (d) Arctic cod Boreogadus saida, (e) Nybelin's sculpin Triglops nybelini, (f) Northern alligatorfish Aspidophoroides olriki, (g) spiny lumpsucker Eumicrotremus spinosus, (h) deepwater redfish Sebastes spp. 
Table 1. List of organisms captured in the BIONESS (B) and in the bottom trawl (T). Species in bold print were the most common species in each group. Where appropriate, the life stage of the organism is indicated (L: larva; J: juvenile; A: adult)

\begin{tabular}{|c|c|c|c|c|}
\hline Phylum & Genus & Species & B & $\mathrm{T}$ \\
\hline Cnidaria & $\begin{array}{l}\text { Aglantha } \\
\text { Atolla }\end{array}$ & $\begin{array}{l}\text { digitale (O. F. Müller) } \\
\text { spp. }\end{array}$ & + & \\
\hline Ctenophora & Beroe & cucumis Fabricius? & + & \\
\hline Chaetognatha & $\begin{array}{l}\text { Sagitta } \\
\text { Sagitta } \\
\text { Eukrohnia }\end{array}$ & $\begin{array}{l}\text { elegans Verrill } \\
\text { maxima (Connant) } \\
\text { hamata (Mobius) }\end{array}$ & $\begin{array}{l}+ \\
+ \\
+\end{array}$ & \\
\hline $\begin{array}{l}\text { Annelida } \\
\text { Polychaeta }\end{array}$ & $\begin{array}{l}\text { Tomopteris } \\
\text { Autolytus }\end{array}$ & $\begin{array}{l}\text { septentrionalis Steenstrup } \\
\text { spp. }\end{array}$ & $\begin{array}{l}+ \\
+\end{array}$ & \\
\hline $\begin{array}{l}\text { Arthropoda } \\
\text { Ostracoda }\end{array}$ & $\begin{array}{l}\text { Conchoecia } \\
\text { Conchoecia }\end{array}$ & $\begin{array}{l}\text { elegans Sars } \\
\text { borealis Sars }\end{array}$ & $\begin{array}{l}+ \\
+\end{array}$ & \\
\hline Copepoda & $\begin{array}{l}\text { Calanus } \\
\text { Calanus } \\
\text { Calanus } \\
\text { Mietridia } \\
\text { Bradyidius } \\
\text { Pseudocalanus } \\
\text { Microcalanus } \\
\text { Scolecithricella } \\
\text { Euchaetâ } \\
\text { Oithona } \\
\text { Heterorhabdus }\end{array}$ & $\begin{array}{l}\text { glacialis Jaschnov } \\
\text { finmarchicus (Gunnerus) } \\
\text { hyperboreus Kroyer } \\
\text { jonga (Libbock) } \\
\text { similis (G. O. Sars) } \\
\text { minutus (Kroyer) } \\
\text { pusillus G. O. Sars } \\
\text { minor (Brady) } \\
\text { norvegica Bocck } \\
\text { similis Claus } \\
\text { norvegicus (Boeck) }\end{array}$ & $\begin{array}{l}+ \\
+ \\
+ \\
+ \\
+ \\
+ \\
+ \\
+ \\
+ \\
+ \\
+\end{array}$ & \\
\hline Malacostraca & Boreomysis & arctica (Krøyer) & + & \\
\hline Mysidacea & $\begin{array}{l}\text { Mysis } \\
\text { Meterythrops }\end{array}$ & $\begin{array}{l}\text { polaris Holmquist } \\
\text { robusta S. I. Smith }\end{array}$ & $\begin{array}{l}+ \\
+\end{array}$ & \\
\hline Amphipoda & $\begin{array}{l}\text { Themisto } \\
\text { Themisto } \\
\text { Themisto } \\
\text { Hyperia } \\
\text { Onisimus } \\
\text { Gammarus } \\
\text { Halirages }\end{array}$ & $\begin{array}{l}\text { compressa Goes } \\
\text { libellula (Lichtenstein) } \\
\text { abyssorum Boeck } \\
\text { galba (Montagu) } \\
\text { litoralis (Kroyer) } \\
\text { setosus Dementieva } \\
\text { fulvocinctus (M. Sars) }\end{array}$ & $\begin{array}{l}+ \\
+ \\
+ \\
+ \\
+ \\
+ \\
+\end{array}$ & \\
\hline Euphausiacea & $\begin{array}{l}\text { Meganyctiphanes } \\
\text { Thysanoessa } \\
\text { Thysanoessa } \\
\text { Thysanoessa }\end{array}$ & $\begin{array}{l}\text { norvegica (M. Sars) } \\
\text { inermis (Krøyer) } \\
\text { longicaudata (Krøyer) } \\
\text { raschi (M. Sars) }\end{array}$ & $\begin{array}{l}+ \\
+ \\
+ \\
+\end{array}$ & $\begin{array}{l}+ \\
+\end{array}$ \\
\hline Decapoda & $\begin{array}{l}\text { Pandalus } \\
\text { Pandalus }\end{array}$ & $\begin{array}{l}\text { montagui (Krøyer) } \\
\text { borealis (Krøyer) }\end{array}$ & + & $\begin{array}{l}\mathrm{A} \\
\mathrm{A}\end{array}$ \\
\hline $\begin{array}{l}\text { Mollusca } \\
\text { Gastropoda }\end{array}$ & $\begin{array}{l}\text { Clione } \\
\text { Spiratella }\end{array}$ & $\begin{array}{l}\text { limacina (Phipps) } \\
\text { helicina (Phipps) }\end{array}$ & $\begin{array}{l}+ \\
+\end{array}$ & \\
\hline Cephalopoda & Gonatus & fabricii (Lichtenstein)? & $\mathrm{J}$ & A \\
\hline $\begin{array}{l}\text { Vertebrata } \\
\text { Osteichthyes }\end{array}$ & $\begin{array}{l}\text { Triglops } \\
\text { Myoxocephalus } \\
\text { Sebastes } \\
\text { Liparis } \\
\text { Hippoglossoides } \\
\text { Triglops } \\
\text { Reinhardius } \\
\text { Bathylagus } \\
\text { Liparis } \\
\text { Gadus }\end{array}$ & $\begin{array}{l}\text { nybelini Jensen } \\
\text { scorpius Linne } \\
\text { spp. } \\
\text { fabricii Kroyer } \\
\text { platessoides (Fabricius) } \\
\text { murrrayl Gunther } \\
\text { hippoglossoides (Walbum) } \\
\text { euryops Goode \& Bean } \\
\text { tunicatus Reinhardt } \\
\text { spp. }\end{array}$ & $\begin{array}{l}\text { J, A } \\
\text { L } \\
\text { J } \\
\text { J, A } \\
\text { L } \\
\text { J } \\
\text { L } \\
\text { L } \\
\text { L } \\
\text { L }\end{array}$ & $\begin{array}{l}\text { A } \\
\text { A } \\
\text { A } \\
\text { A } \\
\text { J, A } \\
\text { A } \\
\text { A } \\
\text { A } \\
\text { A } \\
\text { A }\end{array}$ \\
\hline \multicolumn{2}{|c|}{ Gonostomatidae } & & L & A \\
\hline Myctophidae & & & L & A \\
\hline
\end{tabular}

pods (Table 2). Copepods $(73 \%$ by weight), shrimp (Pandalus montagui, $11 \%$ ), amphipods (mostly Themisto spp., $10 \%$ ) and chaetognaths (mostly Eukhronia hamata, $4 \%$ ) comprised most of the total biomass. Among copepods, specimens $>1 \mathrm{~mm}$ accounted for $88 \%$ of copepod biomass (Calanus finmarchicus/glacialis complex and C. hyperboreus).

The ZCM of each group of organisms (except cnidarians; ANOVA, $F=$ $5.24,2 \mathrm{df}, p=0.019$ ) did not differ between series, allowing the results from the 3 BIONESS series to be pooled. The depth distributions varied markedly among groups of organisms (ANOVA, $F=33.78,7 \mathrm{df}, \mathrm{p}=0.0001$ ) (Fig. 4A). The ZCM of shrimps (marked with the letters ab on Fig. 4A) overlapped with that of mysids (group a) and chaetognaths (group b), but was significantly deeper than all other groups (c to f). Cnidarians (group d), hyperiid amphipods (group e) and pteropods (group f) were found in water significantly shallower than the others. The actual depth range of each group was much wider than ZCM values, since the latter represents a weighted average of the overall depth distribution of the organisms. This suggested that, although the bulk of individuals of each group (expressed by the ZCM values) maintained itself at a 'preferred' depth (related to feeding or physiology), a small proportion of the animals (expressed by the total range of occurrence) was dispersed throughout the water column by other factors (such as vertical advection).

The ZCM exhibited ontogeneticrelated variations for 3 of the copepod species. Early copepodite stages of Calanus finmarchicus/glacialis complex, C. hyperboreus and Pseudocalanus spp. were found in shallower water than the later copepodite and adult stages (Fig. 4B). The depth range of juvenile $C$. finmarchicus glacialis (CI to CIII) varied by $\pm 35 \mathrm{~m}$ about the mean depth of $50 \mathrm{~m}$. Early copepod stages tended to occur in a narrower depth range (upper $150 \mathrm{~m}$ ) 
Table 2. Mean concentration ( $\mathrm{mg} \mathrm{m}^{-3}$ wet weight) sampled over the entire water column for each major zooplankter for each BIONESS series. One-way ANOVAs were computed on $\log _{10}(x+1)$ transformed data. Bold values are significantly higher than the others at the specified probability level. ns: non-significant; $\cdot<0.05$, significant; ${ }^{\prime} \cdot<0.01$, highly significant; $\cdots<0.001$, very highly significant

\begin{tabular}{|c|c|c|c|c|}
\hline & \multicolumn{3}{|c|}{ Series } & \multirow[t]{2}{*}{$\mathrm{p}$} \\
\hline & I & II & III & \\
\hline Shrimps & 4.48 & 14.11 & 3.99 & $\cdots$ \\
\hline Pteropods & 0.38 & 0.83 & 0.78 & ns \\
\hline Mysids & 0.06 & 0.11 & 0.11 & ns \\
\hline Cnidarians & 0.13 & 0.25 & 0.23 & ns \\
\hline $\begin{array}{l}\text { Hyperiid } \\
\text { amphipods }\end{array}$ & 5.17 & 13.31 & 5.23 & $\cdots$ \\
\hline Euphausiids & 0.08 & 0.30 & 0.28 & $\cdots$ \\
\hline Chaetognaths & 1.80 & 2.66 & 2.82 & $\cdot$ \\
\hline Copepods & 41.62 & 55.96 & 48.88 & - \\
\hline Total & 53.83 & 87.69 & 62.64 & \\
\hline
\end{tabular}

than the later stages, which became increasingly scattered as their ZCM moved down the water column.

\section{Diel cycle of vertical distribution}

The bulk of shrimp biomass oscillated daily between 100 and $300 \mathrm{~m}$ (Figs. $5 \&$ 6). The ZCM of shrimp became progressively deeper in the morning hours, reaching its deepest point between 10:00 and 15:00 h (Fig. 6). Light appeared to be the primary factor in determining the ZCM of shrimp (Table 3 ).

Mysids, cnidarians, hyperiid amphipods and euphausiids were captured at shallower depths at the onset of darkness (Fig. 5C to F). Pteropods had an erratic pattern with respect to light, changing from one series to the other. For all groups except shrimp, ZCM was primarily correlated with total depth (Table 3), suggesting vertical

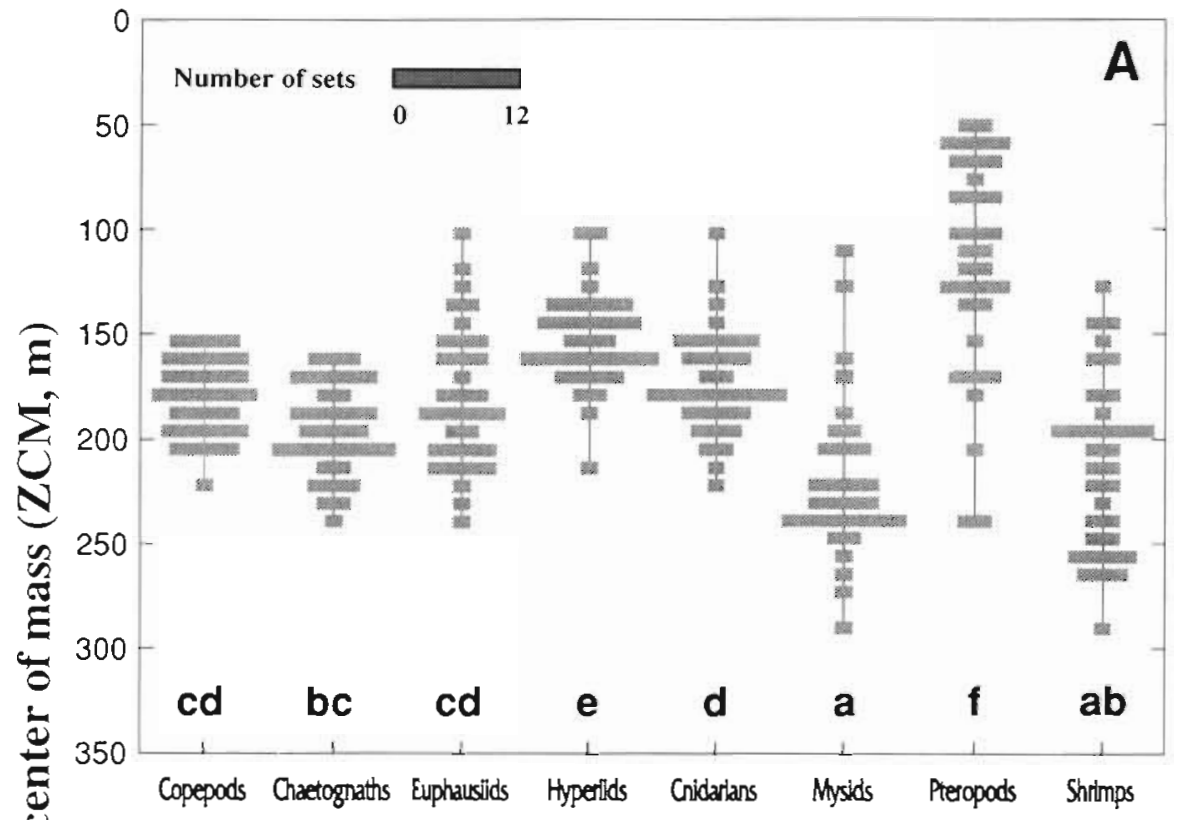

Fig. 4. Vertical range of ZCM observed during the 3 BIONESS series for (A) major groups of macrozooplankters and (B) copepodite stages for the 5 most abundant copepod species. Groups of macrozooplankters distributed at significantly different ZCMs are identified by different letters (see text for more detailed explanation). The line between copepodite stages links the mean ZCM values, showing the progressive descent of older stages 

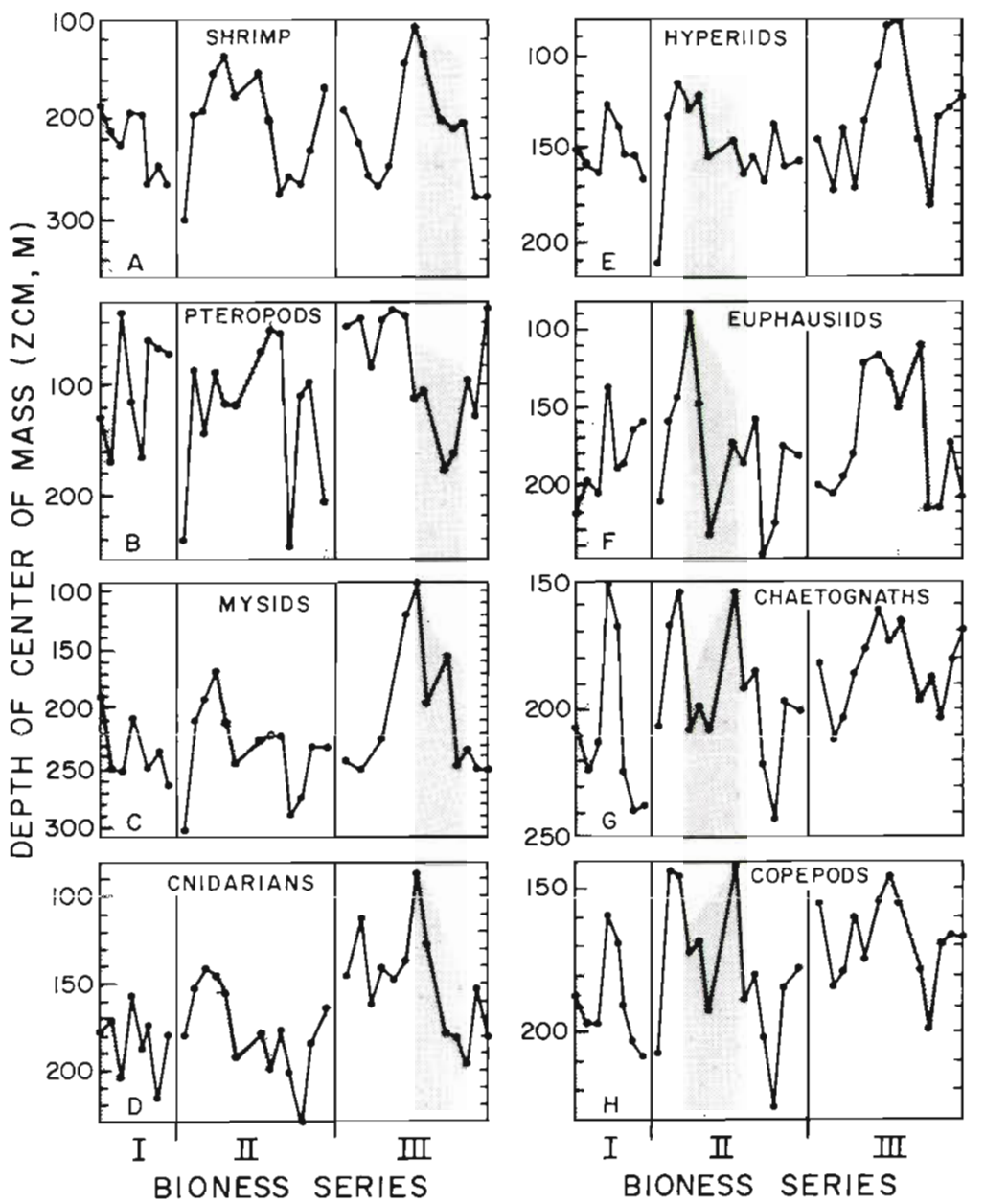

\begin{tabular}{l} 
L \\
\hline
\end{tabular}

Fig. 5. Temporal variations in ZCM of major groups of zooplankters for the 3 BIONESS time series. Shaded areas represent hours of darkness. Data points are at approximately $2 \mathrm{~h}$ intervals. (A) Pandalus montagui, (B) pteropods, (C) mysids, (D) cnidarians, (E) hyperiid amphipods, (F) euphausiids, $(G)$ chaetognaths, $(H)$ copepods

distribution was passively regulated by a common mediating physical factor dependent on bathymetry. The synchronous oscillation of the ZCMs of most groups of organisms in the water column was further supported by the positive correlations between their ZCMs. Correlations were lowest (but still significant) between chaetognaths and shrimp (Pearson $r=0.40, n=34, p=$ $0.02)$ and highest between copepods and chaetognaths $(\mathrm{r}=0.86, \mathrm{n}=34, \mathrm{p}=0.0001)$. Pteropods were not correlated with any other group, consistent with the erratic pattern previously mentioned.

The vertical distributions of cnidarians, chaetognaths and copepods (Fig. 5D, G, H) followed each other closely, but did not demonstrate a clear diel cycle. The oscillations were lagging (or leading) tidal height by about $3 \mathrm{~h}$ in Series II, whereas they were synchronous with tide in Series III. Accordingly, the ZCMs of the 3 groups showed a linkage with tidal amplitude and isopycnal depth, in addition to the effect of bathymetry (Table 3). All species and stages of copepods oscillated synchronously (not shown), regardless of their ZCM (Fig. 4B).

From one BIONESS series to the next, the oscillations of ZCM tended to take place about a shallower average for mysids, euphausiids, hyperiid amphipods, cnidarians, chaetognaths and copepods (Fig. 5). This is consistent with the isopycnal shoaling (Fig. 2a). However, 1-way ANOVA for each group of organisms showed that the mean ZCM did not differ significantly between series (see previous section), possibly due to the large variability in ZCM within series. It is notable that the vertical migrations of the various organisms were all smaller in amplitude than the isopycnal motion at equivalent depths, thus suggesting the additional effect of behaviour on passive displacement.

\section{Acoustic observations of spatial heterogeneity}

Short-term heterogeneity was perceptible with acoustics on the vertical as well as on the horizontal axes (Fig. 7). Even in the absence of obvious bathymetric features, the distribution of the biomass in the water column was patchy and dynamic (Fig, $7 \mathrm{a}, \mathrm{b}$ ). For example, echograms revealed that shrimp were frequently concentrated on either side of a ridge (left side of Fig. $7 \mathrm{c}$ ), with the biomass concentrated in a dense layer in its lee, 10 to $30 \mathrm{~m}$ off the bottom.

The rate of vertical displacement of the scattering layer can be compared with the swimming/sinking speeds obtained for various organisms (Fig. 8). A significant relationship between weight of zooplankters and their sinking rate could only be derived for crustaceans, in contrast to groups characterized by markedly different body density and morphology, such as cnidarians, pteropods and chaetognaths. As expected, the ability to sustain voluntary directional movements increased with zooplankter size (Fig. 8), and corresponded to the zooplankter ZCM range (Fig. 4). Shrimp would migrate upwards at between 3.2 and $5.6 \mathrm{~cm} \mathrm{~s}^{-1}$, which agrees with the measured rate of 
Fig. 6. Pandalus montagui. Hourly plot of shrimp ZCM for each BIONESS set $(n=34)$; results from the 3 series were combined. Shaded areas repre. sent periods of darkness and intermediate light intensities at dawn and dusk

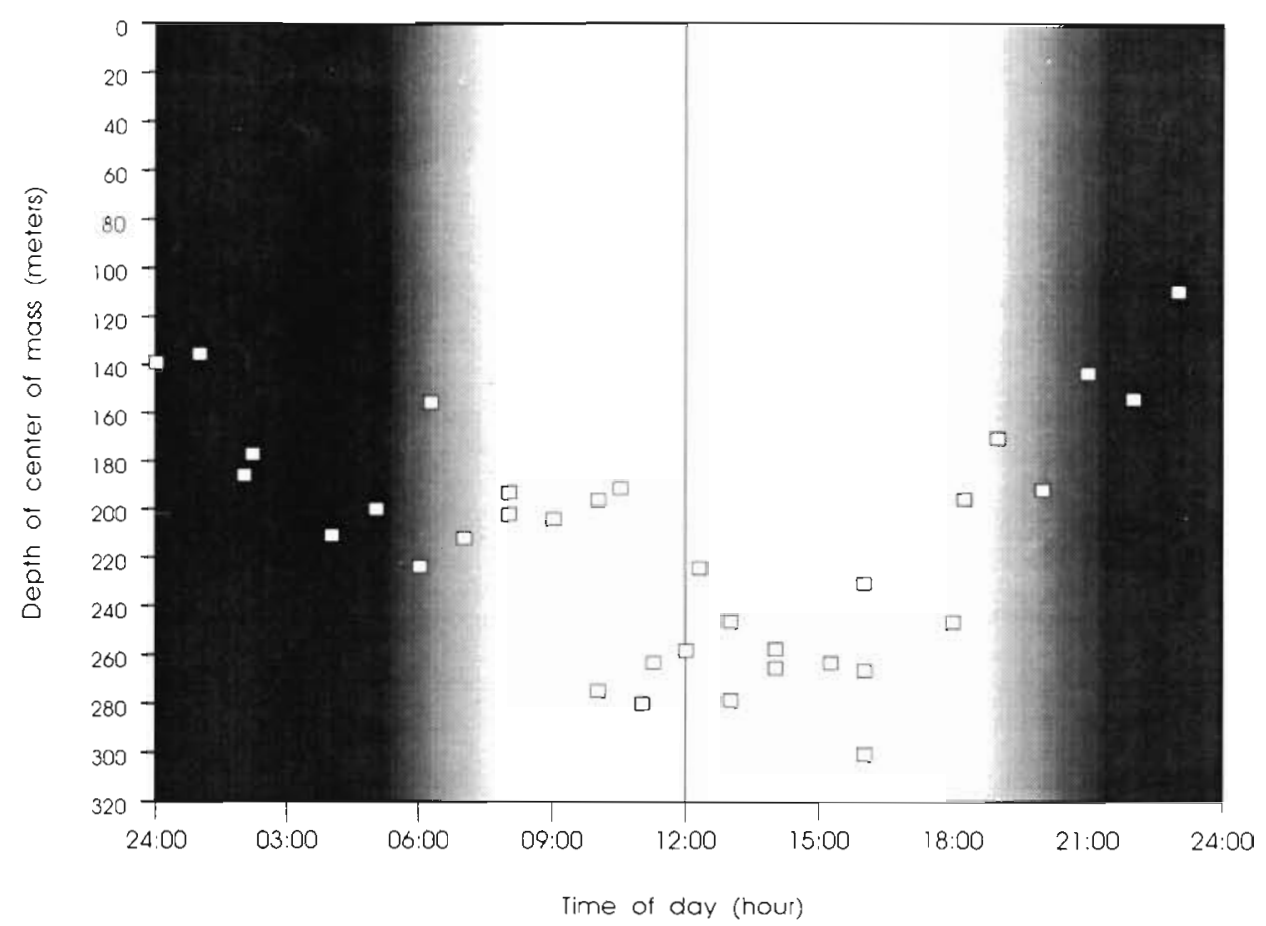

displacement of the dense scattering layer at $4.6 \mathrm{~cm} \mathrm{~s}^{-1}$. In $1 \mathrm{~h}$, shrimp could swim upwards between 113 and $151 \mathrm{~m}$ or sink by 233 to $466 \mathrm{~m}$, if they stopped swimming entirely. Our observation of the duration of upwards shrimp migration $(<6 \mathrm{~h})$ is consistent with our derived values ( 2 to $3 \mathrm{~h}$ ). Migration back to the bottom by sinking could be achieved in about $1 \mathrm{~h}$, which agrees with acoustic observations of the scattering layer.

\section{DISCUSSION}

\section{Horizontal distribution}

The horizontal distribution pattern from trawl samples and acoustics (Fig. 3) shows higher densities of benthic macro-organisms in the trough areas. In addition, the higher concentration of large pelagic organisms (jellyfish and Arctic cod; Fig. 3c, d) captured incidentally in the trawl indicates that the retention mechanism extends through the water column. The highest zooplankton concentrations were located above the trough (BIONESS Series Ii). Comparison of biomass estimates shows that zooplankton concentrations in Series I and III were similar to those observed for Hudson Bay (2 to $18 \mathrm{~g} \mathrm{~m}^{-2}$ ) and neighbouring Frobisher Bay (10 to $18 \mathrm{~g} \mathrm{~m}^{-2}$ ) (E. H. Grainger pers. comm.), whereas Series II, located above the trough, was significantly higher.

Physical forcing may explain the horizontal distribution of zooplankton, fish and shrimp populations.

Evidence for forcing would be revealed by the presence of a front or of a cyclonic eddy. Direct measurement of this could be made with an STD and a current meter. However, current meter data were not collected during the cruise, while STD sampling in the study area was not sufficient to describe the 3-dimensional density field at the scale of the differences found in the biology. We therefore had to resort to examination of the literature for supportive data collected in other studies.

Drinkwater \& Jones (1987) measured the stratification, nutrient concentrations and chlorophyll a levels in Hudson Strait during late summer and found an 

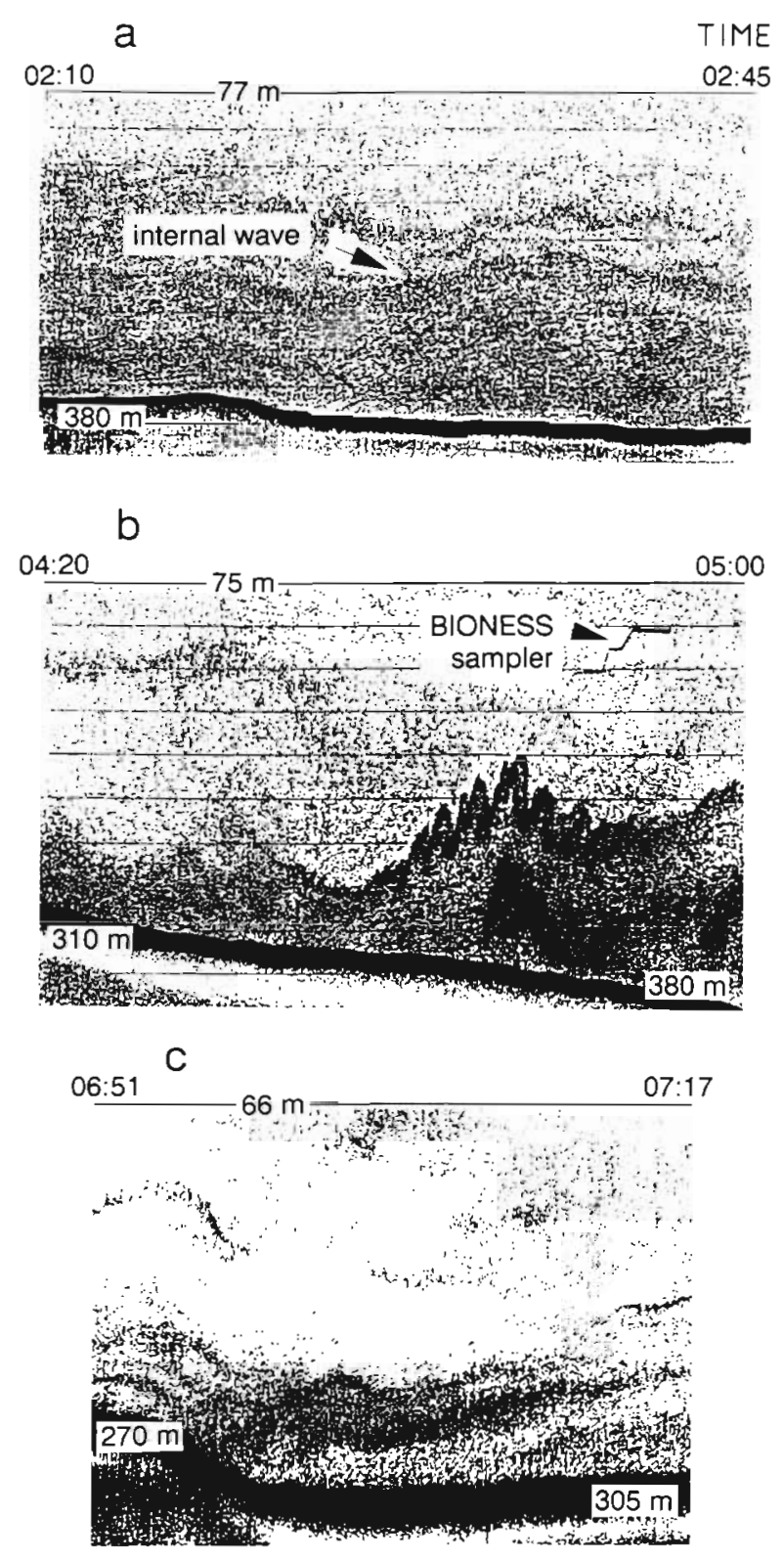

Fig. 7. Echograms from the study area near Resolution Island. Echograms (a) and (b) are from BIONESS Series Il. Echogram (c) was obtained from about the center of the pentagonal study area. The depths indicated at the top and bottom of each echogram refer to transducer and bottom depths, respectively. The time at the beginning and end of each sequence is indicated. (a) At night, small organisms (seen as specks on the echogram) were distributed throughout the water column. The presence of an internal wave was also revealed. Distance shown $=$ ca $3.4 \mathrm{~km}$. (b) As dawn approached, organisms descended near the sea bed. The compounding effect of physical factors on the vertical distribution and movements of organisms was visible, as organisms were concentrated along the edge of internal waves. The path of the BIONESS sampler is also visible. Distance shown $=\mathrm{ca}$ $3.8 \mathrm{~km}$. (c) After dawn, most - but not all - biomass was near the bottom. In this instance, a dense scattering layer occurred about $30 \mathrm{~m}$ above the bottom, in association with a ridge Distance shown $=\mathrm{ca} 3.6 \mathrm{~km}$ area of relatively weak vertical density gradients over the upper $50 \mathrm{~m}$ south of Resolution Island (to the east of our sampling area). Surface to bottom density differences found in our survey were similar to those found in their study. However, Drinkwater \& Jones (1987) reported that surface nutrient and chlorophyll a levels were relatively high compared to regions east of Resolution Island and in most of Hudson Strait west of Ungava Bay. Their findings do not support the presence of a well-defined front in our study region.

LeBlond et al. (1981) showed the trajectory of a surface drifter passing westward into Hudson Strait near Resolution Island. The drifter executed a counterclockwise loop centred about $30 \mathrm{~km}$ southwest of the island, with a tangential velocity of about $20 \mathrm{~cm} \mathrm{~s}^{-1}$. Other factors (e.g. wind) could explain the looping drifter path, but it may also indicate the presence of a cyclonic eddy. If the eddy was a quasi-permanent feature, we might expect raised isopycnals within the eddy, similar to what was observed in our data. Generation of the eddy may be related to bottom topography.

Thomson \& Wilson (1987) and Crawford et al. (1985) showed the importance of bathymetric features for the generation of eddies near the entrance of Queen Charlotte Sound. Retention times for passive drifters increased significantly in these areas. Furthermore, in a study of British Columbia shelf circulation, Freeland \& Mcintosh (1989) and Freeland \& Denman (1982) found the presence of a cyclonic eddy to be related to the bathymetric influence of a small canyon $(>180 \mathrm{~m}$ ). The mean flow orientation and bottom topography of our study area resembles that found in their studies. LeBlond et al. (1981) showed that for stratification levels present $\left(N=6 \times 10^{-3} \mathrm{~s}^{-1}\right)$, the stratification scale ( $f L / N$, where $f$ is the Coriolis parameter, $L$ is a length scale and $N$ is the Brunt-Vaisälä frequency) is sufficiently large that the influence of bottom features extends to the ocean surface in our study region. Although we have no way to confirm the existence of eddy-like features southwest of Resolution Island, the observed biological distribution, bathymetry and the single observation by LeBlond et al. (1981) suggest this to be possible.

\section{Vertical distribution}

Shrimp were found to feed actively on copepods during their nocturnal migrations and also, to a lesser extent, on benthos and suprabenthos in daytime (Hudon et al. 1992). The swimming and sinking speeds calculated for shrimp (Fig 8) agreed well with the acoustic observations. Previous studies have shown that low concentrations of small shrimp remained in the water column during daytime (Hudon et al. 1992) whereas the bulk of the population rapidly 


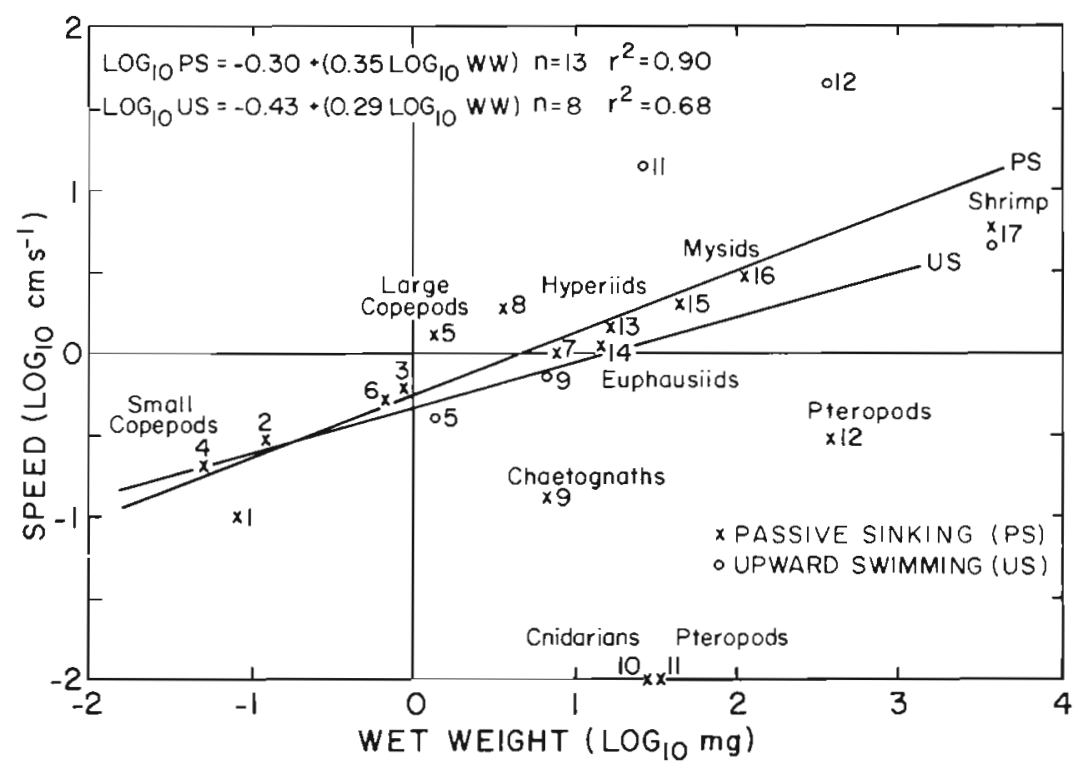

Fig. 8. Linear regressions between upward swimming and sinking speeds $\left(\log _{10} \mathrm{~cm} \mathrm{~s}^{-1}\right)$ and individual wet weight (log $\left.10 \mathrm{mg}\right)$. The regression line labeled 'US' represents predicted values for upward swimming calculated from Hardy \& Bainbridge's (1954) values of sustained swimming (>30 min) for crustaceans (only). The regression line labeled 'PS' represents predicted sinking speed values from Rudyakov \& Tseitlin (1980), as equal to 1 body length $\mathrm{s}^{-1}$. Corresponding speeds are indicated for organisms captured in this study (numbered 1 to 17 ), superimposed on the regression lines. Numbers identify species as follows: (1) $P$ seudocalanus spp.; (2) Metridia longa IIl-IV. (3) V-VI; (4) Calanus finmarchicus I-III, (5) IV-VI; (6) Calanus hyperboreus III-IV, (7) V-VI; (8) Euchaeta norvegica IV-VI; (9) Eukrohnia hamata; (10) Aglantha digitale; (11) Spiratella helicina; (12) Clione limacina; (13) Themisto compressa; (14) Thysanoessa inermis; (15) Metherythrops robusta; (16) Mysis polaris; (17) Pandalus montagui. Values reported for Sagitta elegans, Meganyctiphanes norvegica (Hardy \& Bainbridge 1964), Cavolinia tridentata and Gleba cordata (Gilmer 1974) were used to approximate those of species 9,17,11 and 12, respectively

sunk to the bottom at dawn (Crawford et al. 1992). Consequently, the progressive decline of shrimp ZCM we observed in morning hours (Fig. 6) probably underestimates their actual downward movements, since BIONESS could not sample efficiently the shrimp concentrated near the bottom. Low shrimp concentrations in daytime in the water column would likely be below the detection threshold of acoustics. Daytime residence of the bulk of the population within the benthic boundary layer would attenuate horizontal displacement, thus increasing shrimp retention in the study area. The concentration of juvenile gadids in the benthic boundary layer above the gravel bed of Georges Bank and their dispersion as they undertake vertical foraging (Lough et al. 1989) is a similar example of the interaction of behaviour and water movements affecting spatial distribution. Other groups of less dense organisms, such as pteropods (Gilmer 1974) and chaetognaths (Hardy \& Bainbridge 1954), have comparatively faster swimming speeds per unit of body weight, which explains their deviation from the regression line (Fig. 8). In the case of pteropods, the striking differences in vertical distribution and diel migration pattern (Fig. 5b) can be related to their peculiar morphology and feeding ecology. The 2 pteropod species found in this study be- long to a single, linear food web: the large pteropod Clione limacina is a specialized predator of the smaller herbivorous pteropod species Spiratella helicina (Lalli 1970), the latter being a herbivorous feeder on diatoms, tintinnids and dinoflagellates (Morton 1954).

At the other end of the size/swimming ability scale, chaetognaths, copepods and cnidarians exhibited vertical movements related to water mass characteristics (isopycnal distribution), indicative of passive transport (Table 3). Such passive vertical displacement by internal waves (Haury et al. 1983) and along isopycnal surfaces (Wishner \& Allison 1986) has previously been reported for small zooplankters. The intersection of regression lines for upwards swimming and passive sinking takes place at a size of $0.7 \mathrm{mg}$, which is the size at which sinking and swimming speed are equal. As a result, crustaceans below this size (corresponding to small copepods) do not have to swim continuously to maintain their vertical position.

Successive instars of copepod species are a particularly interesting group with respect to factors regulating their vertical distribution, since they are morphologically homogeneous as a group and overlap (sometimes ontogenically, e.g. large Calanus spp.) the threshold size of $0.7 \mathrm{mg}$ at which sinking speed equals upwards swimming capability. Copepods weighing 
$<0.3 \mathrm{mg}$ (size $<1 \mathrm{~mm}$ ) |Calanus finmarchicus (stages I to III), all stages of Pseudocalanus spp., Metridia longa (stages III and IV), Calanus hyperboreus (stage II) and Euchaeta norvegica (stage II)] accounted for only $7.2 \%$ of copepod biomass. This is considered to be an underestimate as the relatively large mesh size nets that were used are not efficient in capturing these small-size zooplankters (Vannucci 1968). Early copepodite stages could have been concentrated in the euphotic zone to graze phytoplankton, while the bulk of later stages progressively moved to deeper water. The ZCM of the 2 most abundant copepod species exhibited a sharp drop at the copepodite stage reaching a weight $>0.7 \mathrm{mg}$ (C. finmarchicus V, C. hyperboreus IV). These observations are consistent with the increases in sinking rate, swimming ability and migratory capacity as copepods grow in size.

Chaetognaths were found in greatest abundance immediately below the depth of copepod concentration, and their ZCMs were highly correlated, indicating synchronous oscillations. This correspondence likely results from the combined effects of passive displacement and of the important predator-prev relationship between these 2 groups.

Correlations between the diel cycle of vertical distribution and physical factors (Table 3) indicated that only the largest crustaceans (shrimp and mysids) had sufficient swimming power to overcome the physical effects of water advection and pursue their vertical migration in relation to light intensity. For all zooplankters smaller than shrimps, bathymetry was significantly correlated with their ZCM (Table 3). This bathymetric effect was most pronounced for the second series (Fig. 2a, middle panel) when the center of mass of most organisms oscillated in parallel with bottom contour (280 to $370 \mathrm{~m})$. When advected over a bank, organisms would respond either by actively narrowing their depth range or by maintaining it passively, thus increasing the overlap of their depth range. Alternately, their vertical range would widen as the water column deepened. Whether this phenomenon is regulated passively through physical conditions and/or actively through behaviour (for example, adjustment of relative depth with respect to predators, prey or light) remains to be determined. This phenomenon could explain the common appearance of a deep scattering layer associated with bottom topographic features. The presence of internal waves was observed on several occasions in the scattering layer (Fig. 7). The concentration of planktonic organisms along the internal wave surface indicates passive vertical displacement, resulting in a more variable vertical distribution.

The ZCM of cnidarians, which are relatively weak swimmers in spite of their large size, was additionally influenced by tidal amplitude, suggesting an in- creased passive component. The absence of effects other than that of depth on the ZCM of hyperiid amphipods, euphausiids and pteropods (Table 3) could in part be due to the coarser (50 to $100 \mathrm{~m}$ strata) sampling of the surface layer $(0$ to $100 \mathrm{~m}$ ) in comparison with the bottom layer ( $25 \mathrm{~m}$ strata). These organisms comprise herbivorous feeders, which could regulate their distribution primarily according to other factors, such as phytoplankton distribution in the surface layers.

Physical forcing of the vertical distribution of the organisms was dominated by internal tide oscillations. Detailed comparison of the predicted surface tide with the vertical oscillations of isopycnals at the 3 locations was limited by sampling interval ( 2 to $6 \mathrm{~h}$ ), vessel motion around the 'fixed' stations, large horizontal density gradients, weak vertical density gradients and strong tidal flow. Isopycnals oscillated with a semidiurnal periodicity (2 h), with a quarter-diurnal or higher-frequency signal superimposed. The confounding effects of temporal variability on spatial effects cannot be neglected and should be investigated in the future.

\section{Community persistence}

Our results suggest that the physical conditions generated by the bathymetry and flow regime off Resolution Island have multiple consequences on the horizontal and vertical distribution of zooplankters and suprabenthic organisms. We hypothesize that the existence of a retention area generated by a narrow underwater canyon could be the mechanism leading to the concentration of planktonic and suprabenthic organisms forming a primarily plankton-based community. Small zooplankters (copepods and chaetognaths) are concentrated passively and serve as prey items for shrimp, which undertake nightly vertical feeding forays into the water column. Larger zooplankters (such as mysids and pandalid shrimp), which are characterized by a more developed swimming capability, maintain their diel vertical migrations in relation to light intensity. Local retention of pandalid shrimp is enhanced by their daytime concentration in the deeper waters of the canyon in the benthic boundary layer (30 to $40 \mathrm{~m}$ ). Other organisms may also take advantage of this retention mechanism and of the resulting plentiful food resources Pelagic cnidarians, chaetognaths, hyperiid amphipods, predatory pteropods and Arctic cod occur in high concentrations. The combination of physical forcing and specific bathymetric features could thus allow the persistence of this small oasis at the eastern entrance of Hudson Strait. 
Acknowledgements. The help of Vincent Jarry and Georges Lobb in keeping the BIONESS operational was invaluable. Don Parsons, Pat Veitch, John Jorgensen, Jack Fife and John Percy also contributed to the field work. We thank Luc Rainville for the identification and supervision of the analyses of copepodite stages. Yvon Letarte and Guy Préfontaine helped with data entry and statistical analyses. Figures were drafted by Ursula Seidenfuss and Jean-Claude Croteau. The comments of Ken Drinkwater, Bob Conover and 2 anonymous reviewers on an earlier version of the manuscript are acknowledged with thanks. The authors thank the officers and crew of FRV 'Alfred Needler' R.G.I. is supported by the Natural Sciences and Engineering Research Council of Canada.

\section{LITERATURE CITED}

Boucher, J., Ibanez, F., Prieur, L. (1987). Daily and seasonal variations in the spatial distribution of zooplankton populations in relation to the physical structure in the Ligurian Sea front. J. mar. Res. 45: 133-173

Canadian Hydrographic Service (1983). Sailing directions. Labrador and Hudson Bay, 5th edn. Fisheries and Oceans Communications Directorate, Ottawa

Canadian Hydrographic Service (1988). Tides and current tables, Vol. 4. Arctic and Hudson Bay. Fisheries and Oceans Communications Directorate, Ottawa

Cherniawsky, J., LeBlond, P. (1987). The baroclinic circulation in Hudson Strait. Atm.-Ocean 25: 416-426

Crawford, R. E., Fox, J. K. (1992). Visualization of echo sounder data with a microcomputer Can. Tech. Rep. Fish. Aquat. Sci. 1840

Crawford, R. E., Hudon, C., Parsons, D. G. (1992). An acoustic study of shrimp (Pandalus montagui) distribution near Resolution Island (eastern Hudson Strait). Can. J. Fish. Aquat. Sci. 49: 842-856

Crawford, W., Huggett, W., Woodward, M., Daniel, P. (1985). Summer circulation of the waters in Queen Charlotte Sound. Atm.-Ocean 23: 393-413

Denman, K. L., Powell, T M. (1984). Effects of physical processes on planktonic ecosystems in the coastal ocean. Oceanogr. mar. Biol. A. Rev. 22: 125-168

Drinkwater, K. F. (1983). Moored current meter data from Hudson Strait, 1982. Can. Data Rep. Fish. Aquat. Sci. 381

Drinkwater, K. F. (1986). Physical oceanography of Hudson Strait and Ungava Bay. In: Martini, I. (ed.) Canadian inland seas. Elsevier, Amsterdam, p. 237-264

Drinkwater, K. F. (1988). On the mean and tidal currents in Hudson Strait. Atm.-Ocean 26: 252-266

Drinkwater, K. F. (1990). Physical and chemical oceanography. In: Percy, J. A. (ed.) Proceedings of a workshop Marine Ecosystem Studies in Hudson Strait (MESHS) November 9-10, 1989, Montreal, Quebec. Can. Tech. Rep. Fish. Aquat. Sci. 1770 , p. $87-97$

Drinkwater, K. F., Jones, E. P. (1987). Density stratification, nutrient and chlorophyll distributions in the Hudson Strait region during summer and their relation to tidal mixing. Cont. Shelf Res. 7: 599-607

Freeland, H., Denman, K. (1982). A topographically controlled upwelling center off southern Vancouver Island. J. mar. Res. 40: 1069-1093

Freeland, H., McIntosh, P. (1989). The vorticity balance of the southern British Columbia continental shelf. Atm.-Ocean 27: $643-657$

Gilmer, R. W. (1974). Some aspects of feeding in thecosomatous pteropod molluscs. J. exp. mar. Biol. Ecol. 15 $127-144$
Griffiths, D. K., Pingree, R., Sinclair, M. (1981). Summer tidal fronts in the near-arctic regions of Foxe Basin and Hudson Bay. Deep Sea Res. 28A: 865-873

Hardy, A. C., Bainbridge, R. (1954). Experimental observations of the vertical migration of planktonic animals J. mar. biol. Ass. U.K. 33: 409-448

Haury, L. R, Pieper, R. E. (1987). Zooplankton: scales of biological and physical events. In: Soule, D. F., Kleppel, G. S (eds). Marine organisms as indicators. Springer-Verlag New York, p. 35-72

Haury, L. R., Wiebe, P. H., Orr, M. H., Briscoe, M. G. (1983). Tidally generated high-frequency internal wave packets and their effects on plankton in Massachusetts Bay. J. mar. Res. 41: 65-112

Herman, A. W., Sameoto, D. D., Longhurst, A. R. (1981). Vertical and horizontal distribution patterns of copepods near the shelf-break south of Nova Scotia. Can. J. Fish Aquat. Sci. 38: 1065-1076

Hudon, C. (1990). Distribution of shrimp and fish by-catch assemblages in the canadian eastern Arctic in relation to water circulation. Can. J. Fish. Aquat. Sci. 47: 1710-1723

Hudon, C., Parsons, D. G., Crawford, R. E. (1992). Diel pelagic foraging by a pandalid shrimp (Pandalus montagui) off Resolution Island (eastern Hudson Strait). Can. J. Fish. Aquat. Sci 49: 565-576

Lalli, C. M. (1970). Structure and function of the buccal apparatus of Clione limacina (Phipps) with a review of feeding in gymnosomatous pteropods. J exp. mar. Biol. Ecol. 4: $101-118$

LeBlond, P., Osborn, T., Hodgins, D., Goodman, R., Metge, M. (1981). Surface circulation in the western Labrador Sea. Deep Sea Res. 28A: 683-693

Le Fèvre, J., Frontier, S. (1988). Influence of temporal characteristics of physical phenomena on plankton dynamics, as shown by northwest European marine ecosystems. In: Rotschild, B. J. (ed). Towards a theory on biologicalphysical interactions in the world ocean. Kluwer, Dordrecht. p. $245-272$

Legendre, L., Demers, S. (1984). Towards dynamic biological oceanography and limnology. Can. J. Fish. Aquat. Sci. 41 $2-19$

Lough, R. G., Valentine, P. C., Potter, D. C., Auditore, P. J., Bolz, G. R., Neilson, J. D., Perry, R. [. (1989). Ecology and distribution of juvenile cod and haddock in relation to sediment type and bottom currents on eastern Georges Bank. Mar. Ecol. Prog. Ser. 56: 1-12

Mann, K. H., Lazier, J. R. N. (1991). Dynamics of marine ecosystems. Biological-physical interactions in the oceans. Blackwell Scientific Publications, Boston

Morton, J. E. (1954). The biology of Limacina retroversa. J. mar. biol. Ass. U.K. 33: 297-312

Parsons, D. G., Crawford, R. E., Hudon, C. (1990). A hydroacoustical evaluation of the efficacy of bottom trawl surveys for estimating abundance of pandalid shrimp. ICES Shell. Symp. No. 24. ICES, Moncton [mimeo]

Rudyakov, Ya. A., Tseitlin, V. B. (1980). The passive sinking rate of pelagic marine organisms. Okeanologiya 20: 931-936 (Can. Transl. Fish. Aquat. Sci. 4707)

Sameoto, D. D., Jaroszynski, L. O., Fraser, W. B. (1980). BIONESS, a new design in multiple net zooplankton samplers. Can. J. Fish. Aquat. Sci. 37: 722-724

Sinclair, M. Iles, T D. (1989). Population regulation and speciation in the oceans. J. Cons. int. Explor. Mer 45: $165-175$ 
Sprong, I., Kuipers, B. R., Witte, H. (1990). Acoustic phenomena related to an enriched benthic zone in the North Sea. J. Plankton Res. 12: 1251-1261

Thomson, R., Wilson, R. (1987). Coastal countercurrent and mesoscale eddy formation by tidal rectification near an oceanic cape. J. phys. Oceanogr. 17: 2096-21.26

This article was presented by G. C. Harding, Dartmouth, N.S. Canada
Vannucci, M. (1968). Loss of organisms through the meshes In: Tranter, D. J. (ed.) Zooplankton sampling. Monographs on oceanographic methodology 2. UNESCO, Paris, p. 77-86

Wishner, K. F., Allison, S. K. (1986). The distribution and abundance of copepods in relation to the physical structure of the Gulf Stream. Deep Sea Res. 6: 705-731

Manuscript first received: April 8, 1992

Revised version accepted: November 2, 1992 